\title{
LIMBAJUL SACRU AL BISERICII - SIMBOL ŞI ICOANĂ
}

\section{Andrei PetraChE*}

\begin{abstract}
The Sacred language of the Church - symbol and icon'. Language is one of the divine gifts that God granted mankind and therefore it implies, along with the possibility of communicating, a form of communion. To express both the presence of God and the reality of the spiritual world, the Church always used a sacred language, based on symbol, metaphor and image. The plea of this study is in favour of the apophatic theology that uses the sacred and plurisemantic language of the images, opposing to the pure intellectual approach centred on the rationalist enlightenment ideal. For the Orthodox Church there are two distinct plans of existence, surface and depth, two distinct registers of language - conceptualscientific and poeticalimaging. In the first there is reason, thought, conscience, and the words are mirrors that reflect the divine world and in the second are reigning love and symbols, evoking mysteries above words. Of course there is peril along the road: the voided language - the use of concepts or formulas that are devoided of any life and the conceptualization - the attempt to encompass and exhaust the divine mystery and the spiritual world. In addition to verbal language, the Church developed a pictorial language that corresponds to its experience and knowledge of the divine revelation, the icon - which is not considered simple art that illustrates Holy Scripture but a language which corresponds to the evangelical preaching, that is to say, to the content of Scripture, to its meaning.
\end{abstract}

Keywords: language, sacred, communion, apophatism, symbol, icon.

Priest, PhD Student, Faculty of Orthodox Teology at „1 Decembrie 1918” University, Alba Iulia, Romania.

${ }^{1}$ Studiu redactat sub îndrumarea Pr. Prof. Univ. Dr. Marian Vîlciu, care și-a exprimat acordul pentru publicare. 


\section{Introducere}

Conştientizând că funcţia principală a limbajului este aceea de comunicare, Biserica a mărturisit dintotdeauna că puterea de comunicare a fost sădită de Dumnezeu în om pentru ca acesta să nu trăiască izolat, ci în comuniune. De altfel, verbul latin communico nu poate fi limitat la sensul imediat de ,a nota contactul, legătura” - inevitabil superficial şi neangajant -, ci are o semnificaţie mai profundă, însemnând ,a face comun ceva, a împărtăşi, a uni" ${ }^{2}$. Mai mult, acest ultim înţeles, a fost preluat şi în limba română, gravându-1, ,într-un cuvânt vechi şi nealterat de graba şi superficialitatea modernilor”: cuminecare - „,comunicarea este de ceva, cuminecare este în sânul a ceva, întru ceva" ${ }^{3}$. Orice act de comunicare trebuie să provină dintr-o comuniune şi să vizeze constituirea unei comuniuni din ce în ce mai intense; o comunicare ce rodeşte din comuniune şi care vizează comuniunea este o comunicare ontologică, dătătoare de viaţă şi consistenţă.

Scopul acestui studiu este evidenţierea misterului şi a tainei ascunse în adâncurile omului, care îşi revelează prezenţa utilizând limbajul sacru şi plurisemantic al imaginilor, opuse demersului intelectualist axat pe idealul iluminist raţionalist al elucidării suprafeţei solare a lucrurilor, prin reducţia lor la limbajul raţionalist abstract şi univoc al ideilor şi conceptelor, propriu ştiinţelor, politicii şi filozofiei. Pentru Biserică există două planuri distincte ale existenţei, suprafaţa şi profunzimile, două registre distincte ale limbajului - ştiinţific conceptual şi poetic imagistic. Există o teologie a ideilor, care conturează cu evlavie misterul în cunoaştere, şi o teologie apofatică a simbolului. În prima domneşte raţiunea, iar cuvintele sunt oglinzi care, în lumină, reflectă lumea divină, iar în a doua domneşte iubirea, iar simbolurile evocă taine mai presus de cuvinte.

\section{Limbajul secolului: „,limbajul de lemn” şi limbajul ştiinţific}

Una dintre caracteristicile definitorii ale civilizaţiei moderne o constituie tentativa profanului de a invada spaţiul sacrului, tentativă care, deşi eşuată, a avut totuşi repercusiuni la nivelul limbajului eclesial - două

\footnotetext{
${ }^{2}$ Mircea CoRnelıU, Intercomunicare, Bucureşti, Edit. Ştiinţifică şi Enciclopedică, 1979, p. 24.

${ }^{3}$ Ibidem, p. 24.
} 
surogate artificiale care încă mai persistă şi astăzi în Biserică, perturbând teologia ortodoxă: „limbajul de lemn”, adică folosirea unor concepte sau formule lipsite de orice viaţă, şi limbajul ştiinţific, adică tentativa de a cuprinde şi de a epuiza misterul divin şi lumea spirituală.

„Limbajul de lemn”, moştenire a regimului comunist, ascunde în el o limbă încremenită, o limbă obositoare şi anostă a clişeelor. Ea nu îl face pe om să vibreze la auzul vorbelor ci, din contră, îl face insensibil. Din păcate, şi nu trebuie să ascundem acest fapt, încă mai întâlnim şi în Biserică un astfel de limbaj uscat. Avem şi aici de-a face cu persoane care au cules diverse concepte şi formule pe care le reproduc mecanic. $\mathrm{O}$ teologie de manual. Nu înseamnă că aceştia nu mai gândesc, ci că nu mai sunt vii pentru Dumnezeu, în inima lor nu mai ard cuvintele pentru Cel de Sus. Astfel, în mod neintenţionat şi ironic, nişte ,morţi” ajung să ne vorbească despre Dumnezeul cel Viu. Imobilitatea mentală, neputinţa de a scăpa de paralizia lingvistică, este dată de ne-simţirea prezenţei lui Dumnezeu din om. În schimb, adevăratul limbaj al Bisericii, exprimat fie în formă evanghelică, fie liturgică, doctrinară sau spirituală, impune în mod categoric implicarea vie a persoanei în discursul rostit sau scris ${ }^{4}$. Putem caracteriza succint „limbajul de lemn” ca fïind unul vag şi redundant, supraabstractizat, identic în cea mai mare parte, indiferent de autor. Este un limbaj ce utilizează cuvintele într-un fel de incantaţie ideologică, hiperbolizat şi eufemizat ${ }^{5}$, fïind caracterizat de abundenţa verbelor la modul imperativ, mod specific în comunicarea structurilor totalitare. Concepţia psihologică voluntaristă se îmbină cu stilul impersonal, rezultând un limbaj ce reuneşte cele mai importante defecte ale stilurilor de comunicare. Din stilul didactic şi publicistic preia o adevărată manie pentru comparativ, din stilul administrativ, impersonalitatea, iar din stilul ştiinţific, abundenţa substantivelor ${ }^{6}$. Maniheismul reprezintă o componentă fundamentală a acestui limbaj, deoarece discursul schiţează o lume radical divizată în două tabere adverse şi ireconciliabile: materia şi spiritul.

\footnotetext{
${ }^{4}$ Răzvan Ionescu, Adrian Lemeni, Dicţionar de Teologie Ortodoxă şi Ştiinţă, Bucureşti, Edit. Curtea Veche, 2008, p. 177.

5 Lavinia BETEA, „Comunicare şi discurs în «limba de lemn» a regimului comunist”, în Argumentum, 3/2004-2005, p. 48.

${ }^{6}$ Ibidem, p. 49-50.
} 
Reducţia teologiei la un limbaj ştiinţific, adică strict academic, circumscrierea adevărului divin printr-un raţionalism absurd, se datorează unei greşite înţelegeri a teologiei ca ştiinţă şi aplicării ac eloraşi criterii fără a ţine cont de faptul că cele două aparţin unor domenii diferite. Eşecul unei teologii exclusiv speculative, care nu depăşeşte dimensiunea imanentă a limbajului, este incontestabil. Din momentul în care teologia devine doar un act de cultură sau un simplu pretext de creare a unui limbaj specific în care să se reflecte doar motivaţia redusă la plăcerea de a scrie sau a vorbi despre Dumnezeu, ea nu mai poate oferi ceva consistent şi convingător oamenilor. În schimb, adevărata teologie foloseşte un limbaj din care transpare, în mod inteligibil şi coerent, mesajul credinţei în Dumnezeu şi, totodată, în care se reflectă fidelitatea faţă de duhul patristic ${ }^{7}$. Criteriul verificabilităţii limbajului nu trebuie neapărat eliminat însă în domeniul teologiei; corectitudinea limbajului nu poate fi constatată exclusiv pe baza verificării unei realităţi prezente exclusiv în lumea empirică, ci prin fidelitatea faţă de Revelaţie şi prin modul de viaţă strâns legat de experienţa eclesială. În primele trei secole ale existenţei sale, Biserica nu a fost nevoită să prezinte formulări teoretice ale adevărului său, ci 1-a trăit la nivelul experienţei de viaţă, având drept limbaj Evangheliile, epistolele Apostolilor, scrierile apologeţilor ${ }^{8}$. Separată de viaţa eclesială, teologia devine o ştiinţă supusă unor legi şi principii care articulează conceptele şi raţionamentele, automatizându-se în construcţie intelectuală şi în sistem ideologic. Rezumând, teologia Bisericii nu constă într-o minuţioasă cercetare ştiinţifică, ci într-o căutare şi o întâlnire cu Dumnezeul cel Viu. Ea nu obiectivizează adevărul în scheme intelectuale abstracte, adică în reguli şi în principii teologice care pot fi adoptate sub forma unor convingeri ideologice, fără a schimba radical viaţa ${ }^{9}$. Limbajul eclesial nu caută doar adecvarea concepţiilor cu exigenţele unei gândiri formale, ci implică întotdeauna tensiunea relaţiei inter-umane sau a omului cu Dumnezeu. În acest punct, limbajul teologic depăşeşte caracterul speculativ şi întrupează forţa vieţii care devine cuvânt cu putere multă, având menirea de a scoate înţelegerea dintr-o

${ }^{7}$ Răzvan Ionescu, Adrian Lemeni, Dicţionar de Teologie Ortodoxă şi Ştiinţă, p. 177.

${ }^{8}$ Christos Yannaras, Adevărul şi unitatea Bisericii, trad. Daniela Cojocariu, Bucureşti, Edit. Sophia, 2009, p. 25.

${ }^{9}$ Ibidem, p. 51. 
ancorare superficială doar în zona formalului. Puterea cuvântului determină un impact existenţial în cel care-l asumă, nu doar un deliciu intelectual, iar consistenţa cuvântului provine din viaţa pe care o conţine şi pe care o transmite cu convingere celorlalţi. Biserica nu alunecă niciodată pe panta agnosticismului, căci formularea este necesară şi indispensabilă, deoarece delimitează adevărul şi îl distinge de orice deformare sau alterare a sa; ea realizează faptul că limbajul potrivit pentru a răspunde întrebărilor existenţiale ale omului nu poate fi limbajul fizicii sau al geometriei, limbajul volumelor sau al cantităţilor şi al mărimilor de măsurat, ci este un alt limbaj, capabil să articuleze şi să exprime experienţe diferenţiate calitativ şi trăiri ale unor relaţii şi sensibilităţi care revelează o cunoaştere pe care nu o pot asigura simţurile.

\section{Limbajul sacru: simbolul}

Termenul de ,sacru” îşi are originea etimologică în latinescul sacer, ,care înseamnă ceea ce nu poate fi atins fără a întina, dar şi ceea ce nu poate fi atins fără a fi întinat" ${ }^{10}$. În cadrul teologiei creştine ortodoxe, „sacrul” este privit întotdeauna sub aspectul său pozitiv şi înlocuit, cel mai adesea, cu termenul sfânt. În măsura în care „scapă” conceptualizărilor, sacrul este inexprimabil, experienţa personală având un rol esenţial, iar singurul limbaj la care poate recurge Biserica în acest context este simbolul ${ }^{11}$. Cum sacrul ,scapă” oricărei epuizări, înseamnă că nu poate fi cuprins în cuvinte şi nici surprins în totalitate sau definit prin limbajul obişnuit şi prin cel abstract. Putem doar să intuim, să ne folosim de analogii, pentru a înţelege ce putem reda prin limbaj despre „sacru”. Limbajul sacrului nu este, de fapt, limbajul obişnuit ci simbolul, pentru că doar simbolul poate surprinde în acelaşi timp caracteristicile antinomice ale fenomenului religios. Limbajul obişnuit urmează logica binară, logica terţului exclus, conform căreia un obiect nu poate fi în acelaşi timp şi sacru şi profan, sacrul nu poate fi ascuns definitiv şi totuşi manifestat, centrul lumii nu poate fi în acelaşi timp şi omul, şi templul, şi

${ }^{10}$ Basarab Nicolescu, Transdisciplinaritatea. Manifest, trad. Horia Mihail Vasilescu, Iaşi, Edit. Polirom, 1999, p. 148.

11 Julien RIES, Sacrul în istoria religioasă a omenirii, trad. Roxana Utale, Iaşi, Edit. Polirom, 2000, p. 34-35. 
casa. Prin urmare, dificultatea de a exprima sacrul prin limbajul obişnuit constă, pe de o parte, în faptul că limbajul obişnuit, supus logicii aristotelice, nu poate surprinde antinomiile sacrului şi, pe de altă parte, în faptul că sacrul este cunoscut mai profund şi mai intim în misterul său printr-o trăire, o experiere directă sau un sentiment, care nu poate fi redat în cuvinte şi nici cuprins în concepte.

Pentru tradiţia Bisericii, simbolul este ,,semn material care învăluie şi dezvăluie o prezenţă spirituală" ${ }^{2}$, un semn pe care îl înţeleg doar cei care au progresat duhovniceşte, cei neiniţiaţi văzând numai ceea ceea ce este vizibil pentru oricine. Simbolul capătă transparenţă în ochii celui înduhovnicit care vede, prin simbol, pe Dumnezeu şi duce limbajul eclesial spre apofatism, purificând conceptele prin contactul cu ceea ce este inaccesibil şi ferindu-le de închistare în propriile lor sensuri limitate ${ }^{13}$. Acesta determină teologia să folosească un limbaj propriu mai degrabă poeziei şi icoanei decât logicii convenţionale şi noţiunilor ${ }^{14}$. Şi nu este straniu dacă ţinem cont de faptul că însăşi Scriptura foloseşte un limbaj iconic, poetic, împrumutând metafore şi imagini mitice specifice vremii, limbaj ce trebuie descifrat cu atenție, în ambianţa Duhului Sfânt (cf. II Ptr. 1, 20-21). De aceea, limbajul sacru nu poate fi abordat riguros prin hermeneutica modernă atee, demitologizantă, ori prin investigaţia ştiinţifico-literală.

Dacă la cel mai scăzut nivel avem univocitatea, cuvântul care se epuizează prin ceea ce spune şi care este specific cunoaşterii ştiinţifice, caz în care închiderea limbajului este maximă, spre polul opus se situează metafora, care deschide limbajul prin faptul că semnificaţia sa se ascunde dincolo de ceea ce spune, dar care odată cu ,traducerea” acestei semnificaţii îşi poate pierde din deschidere. Simbolul oferă însă cea mai mare deschidere/polisemie. Acesta este obiectiv, pentru că nu este o creaţie a omului, ci îl precede pe om. Astfel, chiar dacă la un moment dat se poate întrevedea un anumit sens al unui simbol, nenumărate alte sensuri rămân de descoperit sau, cum ar spune părintele Stăniloae, numeroase trepte de sensuri rămân de urcat. Insă simbolul nu vorbeşte

\footnotetext{
${ }^{12}$ Nicolae Chițescu, Isidor Todoran, Ioan Petreuță, Teologia Dogmatică şi Simbolică, vol. 1, Cluj-Napoca, Edit. Renaşterea, 2004, p. 128.

13 Vladimir LossKy, Introducere in teologia ortodoxă, trad. Lidia şi Remus Rus, Bucureşti, Edit. Sophia, 2006, p. 36.

${ }^{14}$ Christos Yannaras, Adevărul şi unitatea Bisericii, p. 28.
} 
doar părţii conştiente din om, ci se adresează întregii sale fiinţe, făcând posibilă comunicarea între toate nivelurile fiinţei.

Importanţa simbolului este dată şi de faptul că acesta este o hierofanie. Între două contradictorii, sacrul şi profanul, hierofania este singura care le captează pe amândouă, pentru că este manifestarea sacrului în profan. Simbolul, ca formă de hierofanie, captează această revelare, alături de alte hierofanii: mit, ritual, şi chiar metafora artistică în măsura în care permite nevăzutului să se reveleze. La fel ca şi în cazul cunoaşterii divine, a cunoaşterii ştiinţifice, şi în cazul cunoaşterii sacrului, respectiv a terţului ascuns, am putea vorbi de ,incompletitudinea cunoaşterii”. Dacă în primul caz mai degrabă cunoaştem, în al doilea caz ne dăm seama că mai degrabă nu cunoaştem, ideea de incompletitudine fiind cea care le uneşte. De aceea, în faţa acestei incompletitudini, un limbaj care se vrea precis şi, prin urmare, închis, rămâne comunicare mută. Logica terţului exclus rămâne neputincioasă în faţa acestor contradicţii: şi cunoscut şi necunoscut; şi revelat şi ascuns pentru totdeauna; şi transcendent şi imanent. Doar prin logica terţului inclus aceste contradicţii se pot concilia.

\section{Limbajul vizual: icoana}

Cuvintele sunt icoane ale lucrurilor. Astfel, chiar dacă în cuvânt predomină sensul, iar în imagine forma, nici sensul nu exclude forma, nici forma nu e lipsită de sens. Precum imaginea se referă la vedere, iar cuvântul la auzire, ochii şi urechile pot face ca semnificaţia să fie mai precisă, cunoaşterea mai adâncă şi comunicarea mai bogată. Imaginea este un cuvânt exprimat mai incisiv, care, fïnd materializat, a devenit permanent, iar cuvântul este sufletul oricărei imagini, mai viu decât aceasta din urmă, mai interior; comunicare mai nemijlocită de la persoană la persoană. În cuvânt, fie acela care vorbeşte, fie ceea ce s-a spus, sunt prezente într-un mod mult mai intens decât cel care pictează sau ceea ce s-a pictat. Etimologic, termenul ,icoană” provine din grecescul eikôn şi înseamnă ,imagine” sau ,portret”. Pe vremea când imaginile creştine erau în formare ${ }^{15}$, Biserica desemna prin acest cuvânt orice reprezentare

${ }^{15}$ Pentru a-i obişnui treptat pe oameni cu realitatea de negândit a Întrupării, Biserica li sa adresat iniţial într-un limbaj mai accesibil decât imaginea directă. Aceasta este una 
a lui Hristos, a Fecioarei, a unui sfânt, a unui înger sau a unui eveniment din istoria sfântă, chiar dacă acea imagine era pictată sau sculptată şi indiferent de tehnica cu ajutorul căreia a fost elaborată ${ }^{16}$. Astfel, atunci când vorbim despre icoane, avem în vedere imaginile sacre în general: picturi pe lemn, fresce, mozaicuri şi sculpturi. Pentru Biserică, icoana nu este simplă artă care ilustrează Sfânta Scriptură, ci un limbaj care îi corespunde nu literei biblice ci propovăduirii evanghelice, adică tocmai cuprinsului Scripturii şi sensului ei. Icoana are în Biserică acelaşi rol ca Scriptura, întrunind aceeaşi semnificaţie liturgică şi dogmatică. Prin aceasta, conţinutul Sfintei Scripturi nu este transmis sub forma unei doctrine teoretice, ci în chip liturgic, adică într-un mod viu, care se adresează tuturor facultăţilor umane, printr-un adevărat limbaj pictural care corespunde experienţei şi cunoştinţelor Bisericii referitoare la revelaţia divină.

Icoana este, potrivit unei definiții clasice, "fereastră deschisă spre cer" ${ }^{17}$, pentru ca, prin materie, să se poată vedea ceea ce este nevăzut, iar ceea ce este pământesc să se unească cu ceea ce nu este pământesc. Aceasta este manifestarea sacrului în mod continuu în lume, pentru că, prin sfințire, devine purtătoare de har și creeazăun spațiu sacru împrejurul său. Scopul imaginii constă în manifestarea cât mai fidelă şi cât mai completă a adevărului Întrupării divine - atât cât o permit mijloacele artei. $\mathrm{Nu}$ carnea pieritoare sortită descompunerii este reprezentată, ci carnea transfigurată, iluminată de har. Aceasta transmite condiţia îndumnezeită a prototipului ei şi îi poartă numele şi, tocmai de aceea, harul specific prototipului se regăseşte în ea. Altfel spus, harul Sfântului Duh este cel care trezeşte sfinţenia deopotrivă în persoana reprezentată şi în icoana ei, iar în el se operează relaţia dintre credincios şi sfânt, prin mijlocirea icoanei celui din urmă. Putem spune că icoana participă la sfinţenia prototipului său iar prin ea participăm, la rândul nostru, cu ajutorul rugăciunii, la această sfinţenie. De exemplu, icoana Mântuitorului ne

din principalele cauze ale abundenţei de simboluri din primele veacuri ale creştinismului. Cf. Leonid UsPensky, Teologia icoanei în Biserica Ortodoxă, trad.

Teodor Baconsky, Bucureşti, Edit. Anastasia, 1994, p. 12-13.

${ }^{16}$ Ibidem, p. 9.

17 Pavel Florenski, Iconostasul, trad. Boris Buzilă, Bucureşti, Edit. Anastasia, 2009, p.

212-217. 
arată ceea ce le-a fost revelat Apostolilor pe muntele Tabor; nu contemplăm doar chipul lui Iisus Hristos, ci şi slava, lumina dumnezeiescului Său adevăr, pe care ochii noştri îl pot vedea graţie limbajului simbolic al icoanei - ,împlinire obşteşte văzută prin picturi’’18. Dar cum se poate traduce pictural o astfel de iluminare, o lumină care străluceşte mai mult ca soarele? Desigur că lumina materială a soarelui nu poate fi decât o imagine a luminii divine necreate, o imagine şi nimic mai mult. Pe de altă parte, icoana trebuie totuşi să corespundă textelor sacre, care sunt absolut explicite: nu este vorba de o imagine poetică şi nici de vreo alegorie, ci de o realitate concretă, o realitate care se cere tălmăcită! Lumea spirituală în care omul a devenit sălaş al lui Dumnezeu ne este dezvăluită cu ajutorul culorilor, formelor şi liniilor, cu ajutorul realismului simbolic - un limbaj pictural unic în felul său. Ordinea şi pacea lăuntrică despre care vorbesc Sfinţii Părinţi ne sunt transmise prin pacea şi armonia exterioară din icoană: întregul trup al sfântului, toate detaliile, până şi părul sau ridurile, chiar şi veşmintele şi tot ceea ce îl înconjoară - totul este unificat şi armonizat. Avem aici manifestarea unei victorii asupra divizării şi haosului interior din om şi, prin om, manifestarea unei victorii asupra divizării şi a haosului dinăuntrul umanităţii şi a lumii.

Este incontestabil faptul că civilizaţia actuală este dominată de cultura imaginii, de cultura limbajelor simple fără ca, totuşi, oamenii să fie iniţiaţi într-o lectură a imaginii. În consecinţă, gândirea este redusă la raţionalism, iar omul nu mai are capacitatea de a citi medierea simbolică a imaginii. Fără împărtăşirea unei realităţi mai profunde şi fără capacitatea de comunicare, imaginea devine propria sa raţiune: izbeşte, atrage, supune, seduce etc. Icoana însă are mereu un limbaj complex, doar în aparenţă simplu: pentru că este imagine şi, în acelaşi timp, cuvânt, este revelaţie şi, în acelaşi timp, anamnesis sau amintire. Fascinaţia icoanei constă tocmai în această extraordinară unitate a cuvântului-imagine, care implică, la nivel psihologic-comunicativ, viziunea totală asupra lumii: pe de o parte, unitatea între concept şi sentiment, între raţionament şi intuiţie în om iar, pe de alta, întâlnirea lui Dumnezeu cu omul, a harului cu natura, a veşniciei cu timpul. Limbajul icoanei însă nu este nici conceptual, nici

${ }^{18}$ Leonid Uspensky, Teologia icoanei în Biserica Ortodoxă, p. 77. 
sonor; nu are acea violenţă a rumorii sau a evidenţei. Vorbeşte, dar nu oricui, ci numai aceluia care o priveşte, şi nu deranjează, în nici un fel, pe acela care nu vrea să o vadă. Ba chiar şi celui care o priveşte îi vorbeşte cu multă discreţie. Aşadar, mesajul icoanei trebuie căutat în direcţia vederii sau a privirii, a acţiunii ochilor, care percep realitatea în armonie $\mathrm{cu}$ alte simţuri.

\section{Concluzii}

Spre deosebire de limbajul sec, ancorat în domeniul formalului şi care foloseşte concepte şi formule lipsite de viaţă, limbajul autentic eclesial implică întotdeauna tensiunea relaţiei inter-umane şi a omului cu Dumnezeu şi nu poate fi decât sacru, din el izvorând, în mod inteligibil şi coerent, cuvântul cel viu al lui Dumnezeu. Mijloacele de manifestare ale limbajului sacru al Bisericii sunt simbolul şi icoana: „omul nu poate sesiza pe Dumnezeu decât prin imagini, prin simboluri. Imaginile umane sunt cea mai înaltă formă de sesizare a spiritului divin, căci, ca imagine în care se exprimă spiritul uman, ele sunt totodată simboluri ale spiritului divin, după al cărui model este spiritul uman”. În același timp însă, „omul nu trebuie să confunde imaginile sale și nici chiar trupul său cu însăşi realitatea sa spirituală. [...] cu atât mai puțin trebuie să transpună asupra spiritului divin latura de obiect a imaginilor. Când se face aceasta, se naște idolul sau mitul. În sensul acesta, orice imagine poate deveni mit, [...]. Chiar și imaginile revelației pot deveni în acest caz mituri" 19 .

\section{Referinţe bibliografice:}

1. BETEA, La vinia, „Comunicare şi discurs în «limba de lemn» a regimului comunist", în Argumentum, 3/2004-2005, p. 36-64;

2. Chițescu, Nicolae/Todoran, Isidor/Petreuță, Ioan, Teologia Dogmatică şi Simbolică, vol. 1, Cluj-Napoca, Edit. Renaşterea, 2004;

3. CORNEliu, Mircea, Intercomunicare, București, Edit. Ştiinţifică şi Enciclopedică, 1979;

4. FloREnSKI, Pavel, Iconostasul, trad. Boris Buzilă, Bucureşti, Edit. Anasta sia, 2009;

${ }^{19}$ Dumitru Staniloae, ,Revelația prin acte, cuvinte și imagini” în Ortodoxia, 3/1968, p. 375. 
5. IONESCU, Răzvan, LEMENI, Adrian, Dicţionar de Teologie Ortodoxă şi Ştiinţă, Bucureşti, Edit. Curtea Veche, 2008;

6. LOSSKY, Vladimir, Introducere în teologia ortodoxă , trad. Lidia şi Remus Rus, Bucureşti, Edit. Sophia, 2006;

7. NICOLESCU, Basarab, Transdisciplinaritatea. Manifest, trad. Horia Mihail Vasilescu, Iaşi, Edit. Polirom, 1999;

8. RIES, Julien, Sacrul în istoria religioasă a omenirii, trad. de Roxana Utale, Iaşi, Edit. Polirom, 2000;

9. StĂniloae, Dumitru, „Revelația prin acte, cuvinte și imagini” în Ortodoxia, 3/1968, p. 347-377;

10. USPENSKY, Leonid, Teologia icoanei în Biserica Ortodoxă, trad. Teodor Baconsky, Bucureşti, Edit. Anasta sia, 1994;

11. YAnNARAS, Christos, Adevărul şi unitatea Bisericii, trad. Daniela Cojocariu, Bucureşti, Edit. Sophia, 2009. 